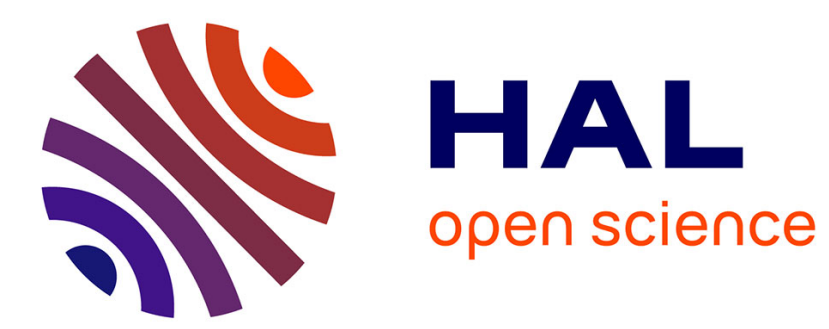

\title{
Plasma spectroscopy for polymer deposition
}

B. Ceccaroli, André Ricard

\section{To cite this version:}

B. Ceccaroli, André Ricard. Plasma spectroscopy for polymer deposition. Revue de Physique Appliquée, 1986, 21 (3), pp.197-199. 10.1051/rphysap:01986002103019700 . jpa-00245430

\section{HAL Id: jpa-00245430 https://hal.science/jpa-00245430}

Submitted on 1 Jan 1986

HAL is a multi-disciplinary open access archive for the deposit and dissemination of scientific research documents, whether they are published or not. The documents may come from teaching and research institutions in France or abroad, or from public or private research centers.
L'archive ouverte pluridisciplinaire HAL, est destinée au dépôt et à la diffusion de documents scientifiques de niveau recherche, publiés ou non, émanant des établissements d'enseignement et de recherche français ou étrangers, des laboratoires publics ou privés. 


\title{
REVUE DE PHYSIQUE APPLIQUÉE
}

Classification

Physics Abstracts

$52.40-52.80$

\section{Plasma spectroscopy for polymer deposition}

\author{
B. Ceccaroli and A. Ricard (*)
}

Saint Gobain Recherche, B.P. 135, F-93304 Aubervilliers Cedex, France

(*) Laboratoire de Physique des Gaz et des Plasmas, Associé au C.N.R.S., Université de Paris-Sud, 91405 Orsay, France

(Reçu le 31 janvier 1985, révisé le 10 octobre, accepté le 29 novembre 1985)

\begin{abstract}
Résumé. - La spectroscopie optique de plasmas pour le dépôt de polymères a été réalisée dans deux décharges capacitives : LF 10-100 kHz et HF 13,6 MHz à des pressions de gaz entre 1 et 2 torr et des puissances électriques moyennes de 10 à 30 Watts. L'émission de la lueur négative proche du substrat a été analysée par spectroscopie d'émission et d'absorption. Des mélanges d'argon avec des gaz réactifs (1-10\%) tels $\mathrm{H}_{2}, \mathrm{O}_{2}, \mathrm{C}_{2} \mathrm{H}_{2},\left(\mathrm{CH}_{3}\right)_{6} \mathrm{Si}_{2} \mathrm{NH}$ et $\left(\mathrm{CH}_{3}\right)_{3} \mathrm{SiOC}_{2} \mathrm{H}_{5}$ ont été étudiés. Les émissions optiques d'espèces spécifiques ont été identifiées dans chaque mélange de gaz. L'ionisation et les intensités des espèces réactives ont été trouvées plus intenses en LF qu'en HF. Inversement, les niveaux métastables $\operatorname{Ar}\left({ }^{3} \mathrm{P}_{2}\right)$ sont plus peuplés dans la décharge HF. Les émissions des impuretés telles $\mathrm{CN}$ et $\mathrm{N}_{2}$ dans l'argon sont discutées.
\end{abstract}

\begin{abstract}
Optical spectroscopy of plasma for polymer deposition has been performed for two capacitive discharges : LF 10-100 kHz and HF 13.6 MHz at gas pressure of 1-2 torr and mean electrical power of 10-30 Watts Emission of the negative glow near the substrate was analysed by emission and absorption spectroscopy. Mixtures of argon with reactive gases (1-10\%) such as $\mathrm{H}_{2}, \mathrm{O}_{2}, \mathrm{C}_{2} \mathrm{H}_{2},\left(\mathrm{CH}_{3}\right)_{6} \mathrm{Si}_{2} \mathrm{NH}$ and $\left(\mathrm{CH}_{3}\right)_{3} \mathrm{SiOC}_{2} \mathrm{H}_{5}$ have been investigated. Optical emissions of specific species have been identified in each gas mixture. Ionization and intensity of reactive species were found to be higher in LF than in HF. Inversely in the HF discharge the $\operatorname{Ar}\left({ }^{3} P_{2}\right)$ metastable levels were more populated. Impurity emissions such as from $\mathrm{CN}$ and $\mathrm{N}_{2}$ in argon are discussed.
\end{abstract}

\section{Introduction.}

In order to better understand the mechanisms of reactions associated with plasma deposition and to control the processes themselves, there is a need for specific in situ diagnostic techniques. Optical spectroscopy is particularly useful in this respect since it is a non-intrusive method which provides information concerning the density of the excited plasma species and their spatial distribution in the plasma surrounding the substrate. To date, most attention has been focused on emission rather than absorption, because the former are easier to adapt to a large range of plasma processes. In the glass industry, reactors are commonly used with d.c. or low frequency (LF) discharges to avoid the effects of outside radiation.

But more basic results are now obtained with the
13.6 $\mathrm{MHz}$ (HF) discharges such as the plasma potential characteristics [1] and the correlation between the active species and the polymerization rate [2]. This paper reports a study of both emission and absorption spectroscopy in glow discharges used for plasma polymerization. The results are given for two LF and HF discharges.

\section{Experimental.}

The discharges investigated were produced in a reaction chamber used for plasma polymerization. The general arrangement of spectroscopic measurements is given in figure 1. Experiments have been performed with two kinds of capacitive discharges LF $(10-100 \mathrm{kHz})$ and $\mathrm{HF}(13.6 \mathrm{MHz})$, at gas pressure of 1-2 torr, and mean incident power of 10-30 Watts. The 


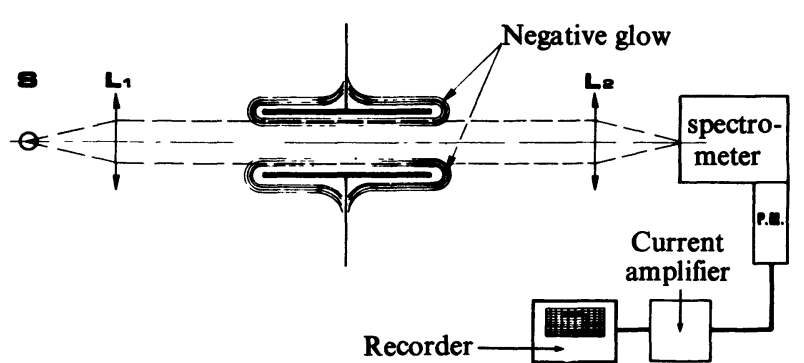

Fig. 1. - General lay-out of the spectroscopic measurements. Spectrometer : HRS Jobin-Yvon; PM : Photo-multiplier RTC type TVP.

distance between the brass electrodes (diameter $13.6 \mathrm{~cm}$ ) was 1 or $2 \mathrm{~cm}$. In these conditions a thin negative glow $(2 \mathrm{~mm})$ was observed surrounding the electrodes in LF with a cathode dark space of about $1 \mathrm{~mm}$. A more diffuse negative glow near the substrate (at the ground potential) was observed in HF. The composition of the gases feed to the discharge was either $\mathrm{H}_{2}, \mathrm{O}_{2}, \mathrm{C}_{2} \mathrm{H}_{2}$, trimethylethoxysilane or hexamethyldisilazane, diluted with argon $(90-99 \%)$.

\section{Results and discussion.}

3. 1 ARGON IONIZATION IN LF AND HF DISCHARGES. Emission spectra in the region from 300 to $900 \mathrm{~nm}$ have been recorded for $\mathrm{LF}(10-100 \mathrm{kHz})$ and $\mathrm{HF}(13.6 \mathrm{MHz})$ discharges of argon at identical gas pressure (1 torr) and in the same range of incident power (20-30 Watts). When the frequency varies from 10 to $100 \mathrm{kHz}$, no change has been observed in the emission spectra. They exhibit numerous spectral lines which have been assigned to argon, both neutral atoms (I) and positive ions (II).

However at $13.56 \mathrm{MHz}$, spectral lines attributed to Ar II disappear almost completely. This phenomenum in the spectral range $430-454.5 \mathrm{~nm}$ in which Ar II emissions are particularly present and strong, can be seen in figure 2. In the present LF and HF discharges at low pressures (1-2 torr), the argon states are mainly excited by electron collisions. Considering that the excitation thresholds of $\mathrm{Ar}$ I and $\mathrm{Ar}$ II are $13.5 \mathrm{eV}$ and $22.5 \mathrm{eV}$ respectively $\left({ }^{1}\right)$, it would seem that the electrons are more energetic in the LF discharge.

A sharp impulsive light emission of about $2 \mu$ s has been observed in LF at the beginning of each discharge pulse. This impulsive emission is the result of a current impulse of same duration, explaining in part the high Ar II emission in LF discharges.

3.2 ARGon METASTABLE SPECIES IN LF AND HF DISCHARGES. - In reactive-gas argon mixtures, the argon metastable species can only lose their excitation energy through atomic or molecular energy transfer. These transfers can therefore be very useful in the understand-

( ${ }^{1}$ Threshold energy from the $\mathrm{Ar}$ and $\mathrm{Ar}^{+}$ground states.
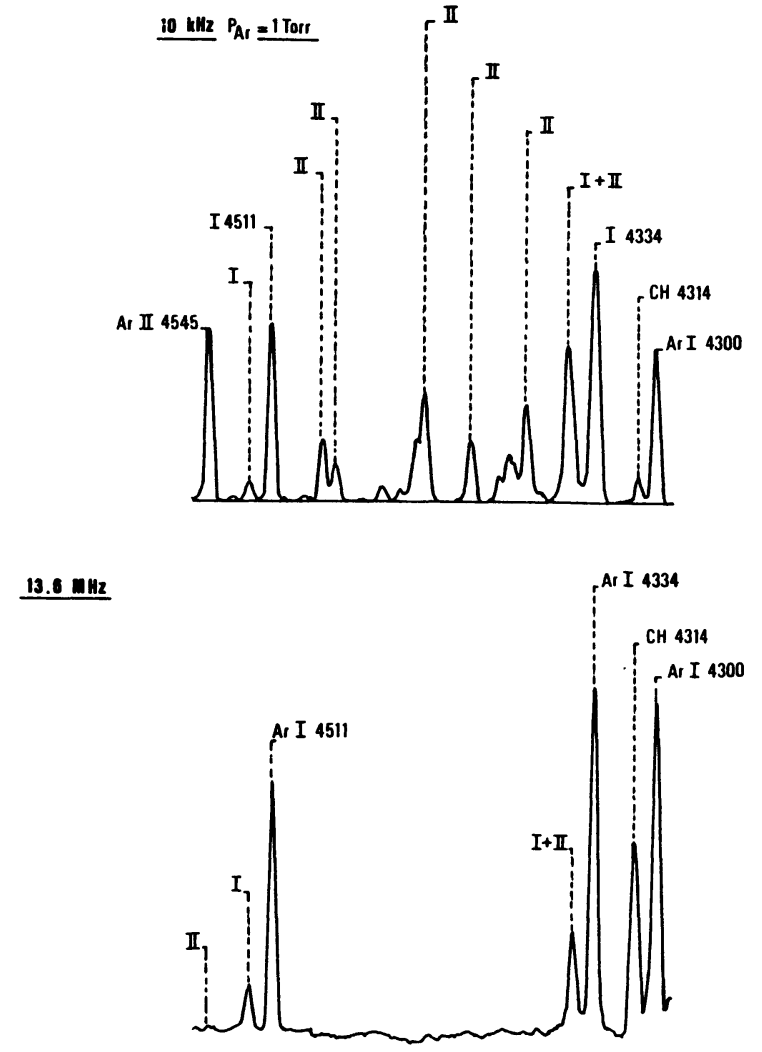

Fig. 2. - Comparison of Ar-spectra at $10 \mathrm{kHz}$ and $13.6 \mathrm{MHz}$ $\left(P_{\mathrm{Ar}}=1.0\right.$ torr, $\left.P=30 \mathrm{~W}\right)$ in the spectral region rich in ionic argon species. (I refers to the neutral species of argon $\mathrm{Ar}$ and II refers to the ionic $\mathrm{Ar}^{+}$.)

ing of plasma chemistry in such media. Densities of $\operatorname{Ar}\left({ }^{3} P_{2}\right)$ metastable atoms have been determined by optical absorption using the line at $696.5 \mathrm{~mm}$. This method is explained elsewhere [3]. Results are reported in table I for argon discharges. They confirm that densities of ${ }^{3} \mathrm{P}_{2}$ are dependent on the plasma parameters especially the pressure and the frequency. In the HF discharge, ${ }^{3} \mathrm{P}_{2}$ is more populated, with a difference of about one order of magnitude, as compared with the LF discharge.

Table I. - Variation of density $n$ of the metastable argon state ${ }^{3} \mathrm{P}_{2}$. The electrical power is about $20 \mathrm{~W}$.

\begin{tabular}{crcl}
$\begin{array}{c}d \\
\mathrm{~cm}\end{array}$ & $\begin{array}{c}F \\
\mathrm{kHz}\end{array}$ & $\begin{array}{c}P \\
\text { torr }\end{array}$ & \multicolumn{1}{c}{$\begin{array}{c}n\left({ }^{3} \mathrm{P}_{2}\right) \\
\mathrm{cm}^{-3}\end{array}$} \\
\hline 1 & 10 & 1 & $3.4 \times 10^{9}$ \\
1 & 10 & 2 & $5.6 \times 10^{10}$ \\
1 & 13600 & 1 & $5.2 \times 10^{10}$ \\
1 & 13600 & 2 & $1.5 \times 10^{11}$ \\
2 & 10 & 1 & $4.5 \times 10^{9}$ \\
2 & 13600 & 1 & $6.4 \times 10^{10}$ \\
\hline
\end{tabular}

3. 3 IMPURITIES EMISSIONS. - The origin of impurities was from outgasing of plasma walls and electrodes. 
Emission spectra have been used to detect impurities in the argon discharges. The impurity emissions were found to be strongly enhanced in the HF discharge. Characteristic lines have been identified for excited states of $\mathrm{N}_{2}, \mathrm{NH}, \mathrm{OH}, \mathrm{CH}$ and especially $\mathrm{CN}$. In the $10 \mathrm{kHz}$ discharge, weak emissions of $\mathrm{OH}$ and $\mathrm{N}_{2}$ have been observed, but the $\mathrm{CN}$ bands have disappeared as is indicated in figure 3 . It is worthwhile noting that the $\mathrm{CN}$ emission in HF decrease and subsequently disappear when the air concentration increases. These impurity emissions in HF can be correlated to the high density of argon metastable atoms shown above. It can reasonably be assumed that $\mathrm{CN}$ emissions like $\mathrm{N}_{2}$ emissions, are produced by energy transfer from the argon metastable states.

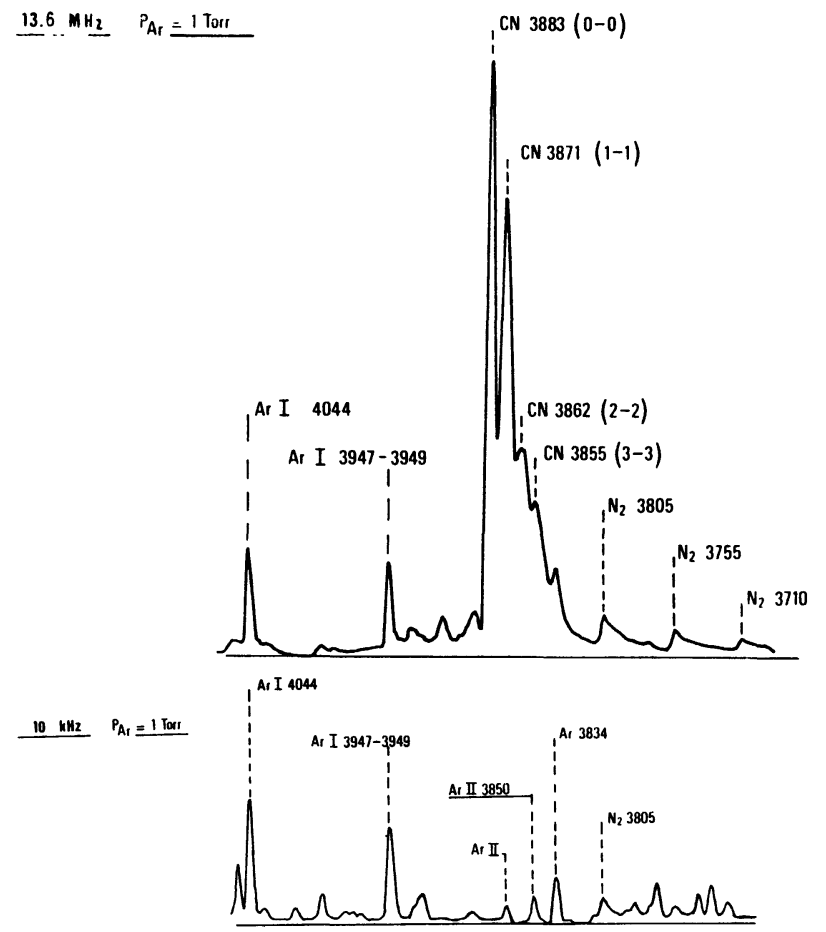

Fig. 3. - Comparison of $\mathrm{CN}$ emissions at $10 \mathrm{kHz}$ and 13.6 $\mathrm{MHz}$ in the same spectral region.

3.4 GAS REACTIVE MIXTURES. - An investigation has been made of the emission spectra of argon (90-99\%) discharges containing the reactive gases, previously cited, in the plasma polymerization processes. At 13.6 $\mathrm{MHz}$ it has been noted that the $\mathrm{CN}$ emissions observed in argon alone disappeared in argon-gas reactive mixtures. Also the argon metastable atoms disappeared in reactive mixtures. These results confirm the hypothesis of $\mathrm{CN}$ production by the argon metastable atoms. Characteristic optical emission lines were also established in each gas mixture and were subsequently used as means of identification i.e.

$$
\begin{array}{ll}
\mathrm{Ar}-\mathrm{H}_{2} & : \mathrm{H}_{\alpha} 656.3 \mathrm{~nm}, \\
& \mathrm{H}_{\beta} 486.1 \mathrm{~nm} . \\
\mathrm{Ar}^{-\mathrm{O}_{2}}: & : \mathrm{OI} 777.3 \mathrm{~nm}, 844.6 \mathrm{~nm} . \\
\mathrm{Ar}-\mathrm{C}_{2} \mathrm{H}_{2} & : \mathrm{H}_{\alpha}, \mathrm{H}_{\beta}, \mathrm{C}_{2} 471.5 \mathrm{~nm} \text { and } \\
& \mathrm{CH} 431.4 \mathrm{~nm} . \\
\text { Ar-organosilanes : } \mathrm{H}_{\alpha}, \mathrm{H}_{\beta} \text { and } \mathrm{CH} .
\end{array}
$$

Similar investigations in LF discharges showed that the emissions resulting from the reactive species were stronger than in HF. For example the intensity ratio $I_{\mathrm{CH}}(431.4 \mathrm{~nm}) / I_{\mathrm{Ar}}(430 \mathrm{~nm})$ were found to be $6.5 \%$ and $65 \%$ at $13.6 \mathrm{MHz}$ and $100 \mathrm{kHz}$ respectively for identical values of electrode distance and gas pressure and about the same mean values of incident electrical powers.

\section{Conclusion.}

Optical spectroscopy of the glow discharges used for polymer deposition has allowed the characterization of excited states in the plasma. Chemical impurities and reactive species introduced in the argon flow have been identified : $\mathrm{H}, \mathrm{O}, \mathrm{OH}, \mathrm{NH}, \mathrm{N}_{2}, \mathrm{CH}, \mathrm{C}_{2}, \mathrm{CN}$. Measurements of line intensities and evaluation of argon metastable state-densities allowed the comparison of $\mathrm{HF}(13.6 \mathrm{MHz})$ and $\mathrm{LF}(10-100 \mathrm{kHz})$ discharges. The former is rich in metastable argon atoms, which give rise to strong emissions from $\mathrm{N}_{2}$ and especially $\mathrm{CN}$ by collision energy transfers. The latter is rich in ionic argon atoms $\mathrm{Ar}^{+}$and reactive species such as $\mathbf{C H}$ and $\mathrm{C}_{2}$. The table II summarizes the active specie intensities found in the two discharges.

Table II. - Active specie intensities in the two discharges - (S) strong, (W) weak - ( $\mathrm{Ar}$ II) argon ionized lines, $\left(\mathrm{Ar}_{\mathrm{M}}\right)$ argon metastable atoms, $\mathrm{X}=\mathrm{CH}$ and $\mathrm{C}_{2}$.

\begin{tabular}{lcc}
\hline & $\mathrm{LF}$ & $\mathrm{HF}$ \\
\cline { 2 - 3 } & $10-100 \mathrm{kHz}$ & $13.6 \mathrm{MHz}$ \\
\cline { 2 - 3 }$I(\mathrm{Ar} I \mathrm{II})$ & $\mathrm{S}$ & $\mathrm{W}$ \\
$n\left(\mathrm{Ar}_{\mathrm{M}}\right)$ & $\mathrm{W}$ & $\mathrm{S}$ \\
$I(\mathrm{X})$ & $\mathrm{S}$ & $\mathrm{W}$ \\
\hline
\end{tabular}

\section{References}

[1] Köhler, K., Coburn, J. W., Hornes, D. E., Kay, E., J. Chem. Phys. 57 (1985) 59.

[2] Smolinsky, C., VAsile, M. J., J. Macromol. Sci. Chem. A 10 (1976) 473.

[3] Pantel, R., Ricard, A., Moisan, M., Beitr. Plasmaphys. 23 (1983) 561. 